\title{
The entrepreneurial nursing care inducing healthy practices in vulnerable communities
}

\author{
O cuidado empreendedor de enfermagem induzindo práticas \\ saudáveis em comunidades vulneráveis \\ El cuidado emprendedor de enfermería induciendo prácticas \\ saludables en comunidades vulnerables
}

\begin{abstract}
How to cite this article: Backes DS, Adames NH, Weissheimer AS, Büscher A, Backes MTS, Erdmann AL. The entrepreneurial nursing care inducing healthy practices in vulnerable communities. Rev Gaúcha Enferm. 2021;42(spe):e20200010 doi: https://doi.org/10.1590/19831447.2021.20200010
\end{abstract}

Universidade Franciscana (UFN). Santa Maria, Rio Grande do Sul, Brasil.

${ }^{\mathrm{b}}$ Hospital Unimed. Santa Maria, Rio Grande do Sul, Brasil.

Hochschule Osnabrück. Osnabrück, Deutschland.

${ }^{d}$ Universidade Federal de Santa Catarina (UFSC). Florianópolis, Santa Catarina, Brasil.

\section{ABSTRACT}

Objective: To understand the meaning of entrepreneurial nursing care as inducer of healthy practices in vulnerable communities. Method: Grounded theory, whose data collection took place between March and December 2019, from interviews with 19 participants from the central region of Rio Grande do Sul, Brazil and comparative data analysis.

Results: The phenomenon was delimited: Experiencing small/big transformations in the invisibility of everyday life in promoting healthy practices in vulnerable communities. Conducted by the paradigmatic model, the categories were named based on the components: Condition: Making choices and negotiating non-negotiable exchanges; Action/interaction: Motivating oneself to maintain basic human needs; Consequence: Broadening perspectives and transcending personal and collective boundaries.

Conclusion: Entrepreneurial nursing care as inducer of healthy practices in vulnerable communities is not reduced to a scientific theory or to the linear and decontextualized apprehension of healthy living, but extends to reach small/big transformations that occur in the invisibility of everyday life.

Keywords: Grounded Theory. Qualitative research. Nursing care. Community health nursing. Unified Health System.

\section{RESUMO}

Objetivo: Compreender o significado do cuidado empreendedor de enfermagem como indutor de práticas saudáveis em comunidades vulneráveis.

Método: Teoria fundamentada nos dados, cuja coleta de dados ocorreu em 2019, a partir de entrevistas com 19 participantes da região central do Rio Grande do Sul e análise comparativa dos dados.

Resultados: Delimitou-se o fenômeno: Vivenciando pequenas/grandes transformações na invisibilidade do dia a dia na promoção de práticas saudáveis em comunidades vulneráveis. Norteado pelo modelo paradigmático, as categorias foram denominadas com base nos componentes: Condição: Realizando escolhas e negociando trocas inegociáveis; Ação/interação: Motivando-se para a manutenção das necessidades humanas básicas; Consequência: Ampliando perspectivas e transcendendo limites pessoais e coletivos. Conclusão: 0 cuidado empreendedor de enfermagem como indutor de práticas saudáveis em comunidades vulneráveis, não se reduz a uma teoria científica ou à apreensão descontextualizada de viver saudável, mas se amplia no alcance de pequenas/grandes transformaçoes que ocorrem na invisibilidade do cotidiano.

Palavras-chave: Teoria Fundamentada. Pesquisa qualitativa. Cuidados de enfermagem. Enfermagem em saúde comunitária. Sistema Único de Saúde.

\section{RESUMEN}

Objetivo: Comprender el significado del cuidado empreendedor de enfermería como inductor de prácticas saludables en comunidades vulnerables.

Método: teoría fundamentada, cuya recopilación de datos fui de marzo y diciembre de 2019, a partir de entrevistas con 19 participantes de la región central del Rio Grande do Sul, Brasil y análisis comparativo de los datos.

Resultados: El fenómeno fue delimitado: Experimentando pequenas/grandes transformaciones en la invisibilidad de la vida cotidiana en la promoción de prácticas saludables en comunidades vulnerables. Conducido por el modelo paradigmático, obtuvo las categorías: Condición: Tomar decisiones y negociar intercambios no negociables; Acción/interacción: motivarse para mantener las necesidades humanas básicas; Consecuencia: ampliar las perspectivas y trascender las fronteras personales y colectivas.

Conclusión: El cuidado empreendedor de enfermería como inductor de prácticas saludables en comunidades vulnerables no se reduce a una teoría cientíica o la aprehensión descontextualizada de una vida saludable, sino que se extiende al alcance de transformaciones que ocurren en la invisibilidad de la vida cotidiana.

Palabras clave: Teoría Fundamentada. Investigación cualitativa. Atención de enfermería. Enfermería en salud comunitaria. Sistema Único de Salud. 


\section{口INTRODUCTION}

The nursing professional has conquered and expanded, in a promising way, his space of multifunctional performance, making nursing a nuclear profession in the structure of health professions, in Brazil and in the world ${ }^{(1)}$. Its advances in the different health scenarios and even in other areas are undeniable. As a science, nursing sought to develop its own body of knowledge, sustained by the frank expansion of graduate programs and the increasing investment in research based on scientific evidence ${ }^{(2-3)}$.

Even though interconnected and complemented by other professional knowledge, nursing can be broadly defined as the science of health care, both in terms of assistance and the protagonism of the care process, as well as in terms of promotion, protection and education health of individuals, families and communities. In this direction, nursing care is configured as an entrepreneurial social practice, made possible by the expansion of professional practice spaces, but, above all, by its recognition in the implementation of various health policies and the maintenance of health care from large centers to most remote locations ${ }^{(4-6)}$.

At international level, scholars point out that Nursing occupies a central place in health systems and services, although it needs to be projected as the profession of the future, in order to ensure access to universal health ${ }^{(6-7)}$. In this discussion area, the nurse professional is challenged by the United Nations program that aims to transform the world based on the Sustainable Development Goals, to definitively assume the leading role in the defense of health care as a universal and non-negotiable social good ${ }^{(8)}$.

At the national level, nursing has been assuming an increasingly prospective role with regard to the identification of the population's care needs, as well as in the promotion and protection of users' health in its different dimensions, above all, due to its proactive and resolutive insertion in different contexts. Constituted by a contingent of more than 2 million professionals, present in the 5,570 municipalities, in the 27 units of the Federation ${ }^{(1)}$, nursing has been based, as already mentioned, one of the promising disciplines in the promotion of public policies and health interventions that are aimed, above all, at consolidating the principles and guidelines of the Unified Health System (Sistema Único de Saúde)(4,9-12).

It emerges in this process of discussions and achievements, the global Nursing Now campaign, based on a partnership between the World Health Organization (WHO) and the International Nursing Council and, in Brazil, between the Federal Nursing Council and the WHO Collaborator Center. Thus, in order to contribute to the advancement of discussions, the research question is: what is the meaning of entrepreneurial nursing care as an inducer of healthy practices in vulnerable communities?

To address the concepts of health, nursing, nursing care, healthy living, vulnerable community and social entrepreneurship in nursing, the present study is based on concepts that refer to the thinking of the complexity and references of social entrepreneurship ${ }^{(5)}$. The objective, based on these theoretical apprehensions, is to understand the meaning of entrepreneurial nursing care as an inducer of healthy practices in vulnerable communities.

\section{METHOD}

It was adopted Grounded theory (GT) as the research method. Based on the natural tendency of people, GT assumes that the social organization of individuals is unique and is dynamic in the daily life of social problems. In this direction, GT provides theoretical explanations about the meaning of the experience of individuals, groups and communities ${ }^{(13)}$.

Data collection took place between March and December 2019, from individual interviews, set in digital voice audio recording with an average duration of 40 minutes. The participants were invited based on a formal invitation and the interviews were previously scheduled and carried out in places indicated by the participants. The theoretical sampling was achieved with 19 participants, distributed into two sample groups: Group 1 workers from a Recyclable Materials Association (G1) and Group 2 students of undergraduate and graduate nursing (G2).

The first sample group was composed by 13 workers from a Recycling Association, located in a vulnerable community in the central region of Rio Grande do Sul, Brazil. From the 28 workers in this Association, 13 were chosen, intentionally, from their employment for at least one year in this same workplace. Based on the meanings attributed to a broad and central question about entrepreneurial nursing care in promoting healthy practices, new questions and hypotheses emerged and directed data collection to a second group. The stages of data collection, analysis and categorization occurred simultaneously and systematically with the comparative data analysis ${ }^{(14)}$.

Based on the data analysis from the first sample group, it was recognized that the meaning of entrepreneurial nursing care as an inducer of healthy practices was strongly associated with (de)motivation to maintain basic human needs, both individual and family. Thus, the data analysis from the first group suggested new questions, such as: what is the meaning of entrepreneurial care and healthy living for undergraduate and graduate students actively placed in 
regular entrepreneurial activities in this same Association? How does this entrepreneurial nursing care materialize in the daily relationships and working conditions? Is it possible for workers in a Recycling Association to promote healthy living? Based on these questions, it was hypothesized that the activities carried out on a regular basis by students, transcend the linear apprehension of healthy living and reach the survival conditions of different family members. Thus, a new data collection was conducted with six students, of which four students from the Nursing Undergraduate course and two stricto sensu Postgraduate students from a Higher Education Institution in the central region of Rio Grande do Sul, Brazil, giving rise to the second sample group. The exclusion criteria for both groups were: workers and students under the age of 18 years.

Data analysis considered the open coding, axial and data integration as proposed by the GT method. In open coding the data was analyzed line by line, in order to identify the incidents, generate the codes and group them in the concepts format. In the axial coding, a new grouping of data was sought in order to enable a comprehensive, objective and clear explanation of the phenomenon. The categories were associated with the subcategories through an analytical and systematic process of comparison and connection, guided by the paradigmatic model composed of three components. Condition: which answers questions about why, when and how a given phenomenon occurs, designated through action; Action/interaction: which constitutes the express response of events or situations that, in some way, contributes to give meaning to the movements (strategies and intervening factors) that define the object of study; Consequence: which reveals the predicted or actual outcomes and results, effects of the action/interaction ${ }^{(13)}$. The phenomenon was delimited from the data integration, that is, from the comparison, analysis and refinement of the categories and subcategories.

Theoretical saturation was based on the repetition of information and the absence of new elements of meaning related to the object of study. As support, memos and diagrams were elaborated based on the researchers' records and insights ${ }^{(13-14)}$. NVIVO software was used to support the organization process and coding data.

The project was approved by the Human Research Ethics Committee, under CAAE 55840116,7,0000,5306. Participants were invited by formal invitation and consented to be part of the research, by signing the Free and Informed Consent Form. To guarantee anonymity, the participants were identified as follows: G1 - workers and G2 - students, followed by a letter $\mathrm{a}, \mathrm{b}, \mathrm{c} . .$. corresponding to the order of the statements.

\section{RESULTS}

The comparative and systematic data analysis enabled the integration of three categories that converged in the phenomenon delimitation: Experiencing small/big transformations in the invisibility of everyday life in promoting healthy practices in vulnerable communities. Guided by the paradigmatic model, the categories were named based on the three components: Condition: Making choices and negotiating non-negotiable exchanges; Action/interaction: Motivating themselves to maintain basic human needs; Consequence: Expanding perspectives and transcending personal and collective limits, as shown in Figure 1.

The condition category"Making choices and negotiating non-negotiable exchanges" is sustained by two subcategories that integrate a complex process of order and disorder in search of a continuous and permanent (self)organization in a personal and family scope. In the first subcategory "Choosing between the possible and the viable", the participants portrayed their harsh reality by mentioning the need to continually choose between what they deem as appropriate and/or viable, such as choosing between eating and/ or resting, between working and/or taking care of health, among other aspects.

I get home and need to bathe, take care of the children, take care of the house [...] I don't have a moment to relax, just to sleep, but I already sleep with my body and head tired [...] (G1a).

We live worried [...] we earn little and have to pay the bills and buy things. All of this interferes with our health. I always have to choose what to do first (G1C).

We are always in that sameness between thinking the money is insufficient, money is not sufficient, the salary is low. It is a continuous stress [...] the politics does not favor, and the government puts everything on your back [...] (G1f).

The subcategory "Dealing with contradictions and uncertainties" showed that working in a Recycling Materials Association means to survive in the midst of everyday oppositions and, generally, in total uncertainty. If, on the one hand, the worker does not have the guarantee of his salary at the end of the month, on the other, he also experiences the pains and anguishes of those who feel marginalized and unprotected by society, according to the statements:

I have my boy who is missing, and they don't want to talk me [...] I don't know if he's dead or alive. I'm even 


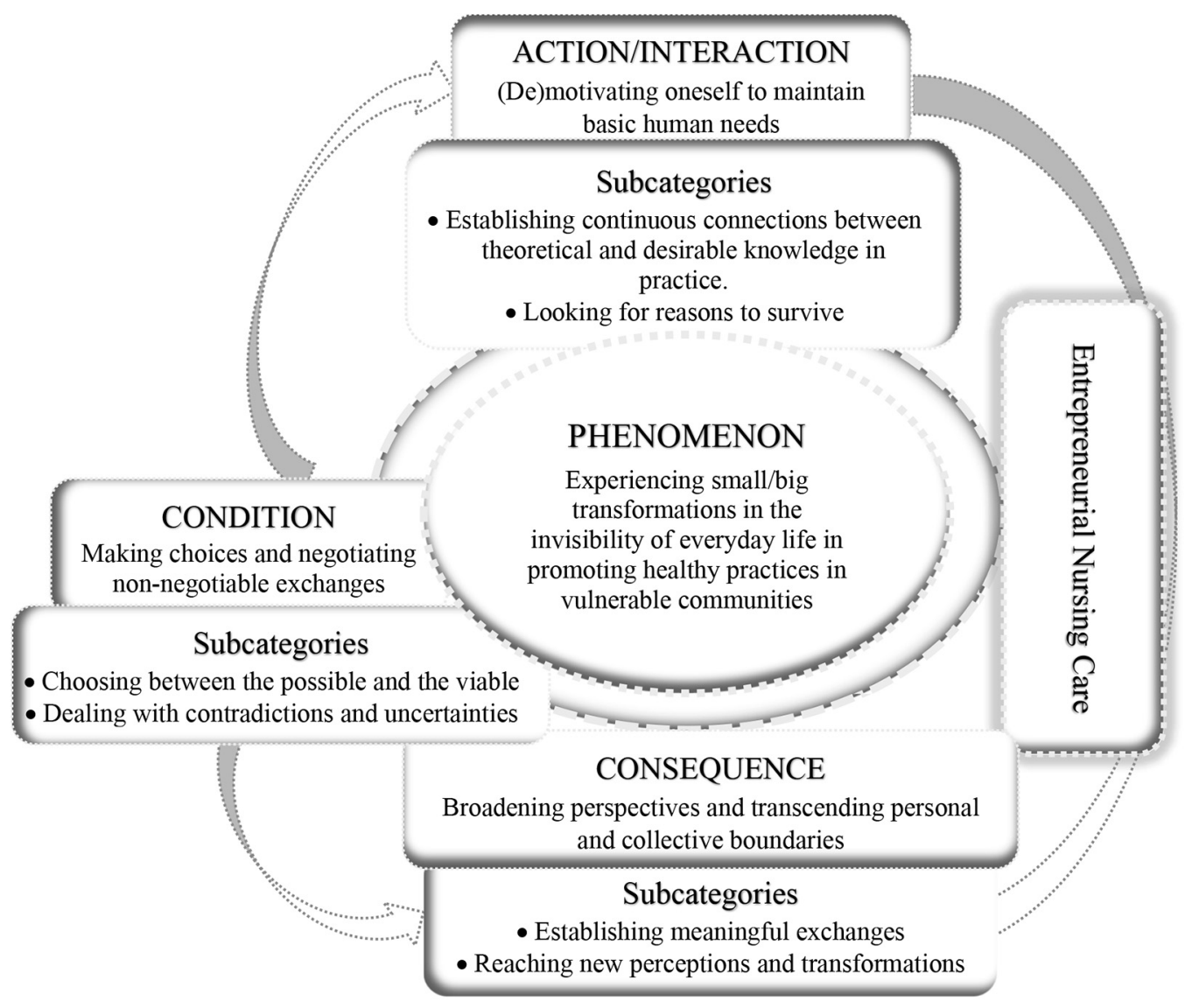

Figure 1 - Phenomenon: Experiencing small/big transformations in the invisibility of everyday life in promoting healthy practices in vulnerable communities Source: Authors, 2019.

afraid to get there 'pause' and they say that he died or to go to the cemetery and find his name there [...] it's an uncertainty every day [...] (G1i).

In the Association it is difficult and even contradictory to develop health promotion of workers, because everything is missing. You have a surprise every day. They live in total uncertainty and insecurity, having to choose between eating or doing something else (G2C).

The action/interaction category"(De)motivating oneself to maintain basic human needs" portrayed the complex reality to maintain the daily dynamics between living/surviving in adverse and vulnerable conditions for which they find no reason. This category is sustained by two subcategories that subsidize the paradox between the real and the desired. In the first subcategory "Establishing continuous connections between theoretical and desirable knowledge in practice", the participants demonstrated knowledge about the meaning of healthy living, although unrealizable in practice.
They showed that healthy living is associated with eating conditions, leisure, rest, finally, life in community. However, financial conditions are below these desired possibilities. This thinking is also corroborated by the students, when they transcend the classroom theories and when facing with the reality of what was experienced by the workers in the Association.

We know that healthy living is related to food, not smoking, physical activities, such as cycling, running, having leisure. But how can I think of it all if I barely get money for food? I would like a lot, but as a recycler it is difficult to have a healthy life (G1j).

I have never before had the opportunity to visit a vulnerable community. With this experience, I ended up developing empathy, active listening and, mainly, the ability to not judge the reality of others without living it. Today I realize that theory needs to dialogue with practice (G2d). 
The subcategory "Looking for reasons to survive" revealed that the work routine in a Recycling Association requires effort and daily struggles to not give up and, minimally, manage to survive. Study participants mentioned that daily work requires persistence and goals capable of extrapolating routine and social invisibility. They feel devalued and alienated from society and claimed that they need to self-motivate, daily, to overcome obstacles.

My routine is very exhausting. Most days I don't feel like working. I come home exhausted, but soon I remember that I need to continue working to support the family. I feel pain all over my body [...] the salary is very low and in the summer it is very hot ( $\mathrm{G} 1 \mathrm{~m})$.

Workers feel unmotivated. We realize that they make an extra effort to survive in the daily life of the Association. They feel devalued by society in general. In our activities, we always look to bring something new and different to motivate them (G2e).

The consequence category "Broadening perspectives and transcending personal and collective boundaries" is supported by two subcategories. The first subcategory "Establishing meaningful exchanges" refers to the support that workers received, above all, from professors and students at the University and from some community supporters who eventually offer them a donation to address basic needs. In particular, they highlighted the regular monthly activities at the Association, carried out by teachers and students, ranging from theoretical-practical workshops on health promotion and education to social gatherings on festive dates, in which they received a beauty treatment and other special pleasures. These exchanges are significant both for the workers of the Association and for the students involved in this project, as shown in the statements below:

I feel a lot of the strong and it gives me a lot of energy when students come here. Everyone has a very good energy. We learned a lot from everyone. If it weren't for them, I don't know what would become of us (G1n).

After several moments with them, I could realize that I became more human and supportive. I learned to take a broader look at the situations that occurred there and to thank for being in this project. A speech by a recycler that made me happy and fulfilled was: Thank you for being here. With each conversation with you, I get better, I am more willing to face the obstacles that we go through [...]. Certainly, this was one of the speeches that
I will never forget and that marked me a lot in these two years of the project. As a future professional, I was able to confirm that I am on the right path and realize that social projects change the way we think and act (G2f).

The subcategory"Reaching new perceptions and transformations" demonstrated that, in addition to prejudice, indifference and social devaluation, there are desires and impulses for transformation, although invisible to the eyes of society. While workers, through their dialogue with students, found reasons to reinvent themselves and dream about new perspectives, students transcended the linear, punctual and prejudiced perception that in a vulnerable community, little and/or nothing is learned. The small/big transformations that occurred in the invisibility of everyday life are notorious, which occurred at the personal, family and community scopes.

It is so good to live with people who are interested in us, who see us as a human person who fights, but who has dreams. I really want at least one of my kids to go to university like these students [...] (G1d).

I never had the opportunity to visit a vulnerable community. So l ended up developing more empathy, active listening and, mainly, the ability to not judge the reality of others without experiencing it. In my academic trajectory, I believe that the responsibility of knowing that my knowledge can impact people's lives makes me dedicate myself more and more (G2a).

I believe that everything that is accomplished in the project is already a way of qualifying, because through the activities a good part of the workers changed their ways of thinking and acting a little, and this is something that is priceless (G2b).

To feel in the skin each process that occurs for having the separation of materials. I managed to bring this experience into my home, where we were not in the habit of separating waste properly [...] / realized how much this separation facilitates and optimizes work in the association (G2c).

The entrepreneurial nursing care, based on the results achieved, is not reduced to the performance of assistance activities or to a theoretical and linear apprehension of the social context. Entrepreneurial nursing care can be evidenced in the small/big transformations of everyday life, that is, in the empowerment of workers and the role of students within this movement. 


\section{DISCUSSION}

Nursing care, as an essential component in the local and global health system, has been the focus of growing and intense debates and clashes, which in no way reduces its meaning and relevance. While scholars ${ }^{(9-12)}$ are concerned in finding arguments to ensure what they defend as "priority nursing care", others ${ }^{(4-5,15-16)}$ focus on the search for tools that expand entrepreneurial opportunities and possibilities. Such paradoxical movements are, therefore, important, complementary, and necessary for the advancement of nursing science.

The discussion of the phenomenon of this study "Experiencing small/big transformations in the invisibility of everyday life in promoting healthy practices in vulnerable communities", is not limited to a discussion that reduces and/or reproduces what is already available or in the domain of nursing/health professionals, but induces complex and prospective thinking. In this direction, questions soon emerge instead of answers: how to foment/expand the entrepreneurial character of nursing? How to enable nursing care that transcends traditional conceptions and hegemonic spaces consecrated by contemporary thinking and acting? What to expect from health users, considered protagonists of their own history? Anyway, what to expect and how to be inserted, autonomously and responsibly, in the Nursing Now campaign?

It was observed, in the speech of the participants of the present research, that there is a paradoxical movement of daily transformations in vulnerable communities, even if in the invisibility and discredit of daily work. Although they recognize the social and environmental relevance of their work, the members of the Association expressed discomfort in having to continually negotiate between the possible and the impossible to maintain basic human needs. In addition, they reinforced the tireless effort to reconcile what they believe to be fundamental and what they consider to be viable to ensure healthy living.

In the search for an expanded and systemic understanding of nursing care and in order to enable effective mechanisms to intervene in the dynamics of healthy living, understood as a unique, circular and interactive process, dynamized through experiences of order and disorder ${ }^{(5)}$, the nurse has been projecting himself as one of the main interlocutors. When conceiving Nursing as a science, art or technology to promote nursing care to the human being in its uniqueness and multidimensionality, articulated with the other professionals committed to the health phenomenon, it is admitted that only a complex thinking of care/attention is able to cope with the paradoxical and contradictory movements of being - being in a continuous process of self-organization to live better - living healthy ${ }^{(4-5,15)}$.

Thinking and defending nursing care as an entrepreneurial social practice, based on the results of this study, implies (re)signifying concepts, transcending spaces, dialoguing with other professional knowledge and interacting with the world of life. It also implies enabling new scientific theories that find resonance in the dynamics of healthy living for users, in this case, members of the Recycling Association, with a view to emancipation as protagonists of their own history. However, which nursing theories can/should be used to account for a broad and systemic perception of health care? Studies denote the need to value nursing theories in order to achieve good health practices. However, there is talk, not of any theory, but of medium-range theories conceived and aligned with practice and supported by the evidence of scientific research, in order to produce robust consistent explanations, descriptions, predictions and prescriptions ${ }^{(17-18)}$. These theories, by the contemporary look, bring us new possibilities to interpret them in their theoretical and philosophical bases, by valuing the healthy living of individuals in their different forms of expression.

In promoting multidimensional care for human beings, as the essence and specificity of the profession, nursing has, by excellence, the possibility of connecting with different fields of knowledge, as well as with different realities and social contexts. Focusing on the human person, the family and the community, in its unique and multidimensional dimension, nursing has the skills and competences to conceive, implement and coordinate health care - complex unit. In addition, nursing has the potential to establish effective channels of communication with the various sectors of society and, thus, ensure more effective and resolving strategies for healthy living, especially in vulnerable communities ${ }^{(4,18-19)}$.

Entrepreneurial nursing care is distinguished, based on these discussions and the results of this study, by the possibility of apprehending human beings in their unit and complex diversity, by the integrality of health care, by the ability to welcome and identify with the needs and user expectations, due to the ability to welcome and understand social differences and promote systemic interactions and associations. The nursing professional, more than any other professional, identifies and looks forward to creating effective bonds with the user, regardless of their ways of life, their economic, cultural, or social conditions. In other words, it strives to optimize care so that it integrates and contemplates both professional knowledge and also knowledge and practices of users and the community ${ }^{(4,20)}$. Nursing is a strong promoter of protagonism and citizenship, in defense of life and better living, with better health and better vitality of being. 
Promoting entrepreneurial nursing care, based on the above, requires, in addition to renewed intervention methodologies, the proactive insertion of nurses in different social and health contexts. It is necessary that he/she knows, in practice, the notions of order and disorder, as well as the contradictions, uncertainties, concerns and the real daily motivations of individuals, in order to establish dialogic processes between technical-scientific knowledge and popular knowledge.

\section{FINAL CONSIDERATIONS}

The entrepreneurial nursing care as an inducer of healthy practices in vulnerable communities is not reduced to a scientific theory or to a linear and decontextualized apprehension of healthy living. The same is broadened and evidenced in the reach of small/big transformations that occur in the invisibility of everyday life, which transcend areas, spaces, beliefs, ideologies, politics, and others.

The results of this study allow us to argue, therefore, that entrepreneurial nursing care, as a social impulse, can be considered a prospective strategy to achieve healthy and advanced practices in different social and health contexts. In short, it is expected that in a year of the Nursing Now campaign, this innovative and transformative thinking is assumed and defended by the nursing professionals themselves. What else to expect from society, since we have already proved that we are an essential and indispensable profession for the sustainability of the health system?

The contributions of this study are associated, however, with the understanding that nursing care has an essential and highly differentiated function, as its socially relevant communication is the healthy well-being of the human being in its multiple dimensions. The nursing professional, more than any other professional, identifies and enables effective connections with the user, regardless of their ways of life, their economic, cultural, or social conditions.

Finally, it should be noted that the results cannot be generalized, considering that the study was based on a specific reality, in which there was a limitation on the number of participants, as well as the delimitation of a single research scenario. It is suggested research in different realities in order to expand theoretical and practical perceptions around entrepreneurial nursing care.

\section{REFERENCES}

1. Silva MCN, Machado MH. Health and work system: challenges for the nursing in Brazil. Ciênc Saúde Coletiva. 2020;25(1):7-13. doi: https://doi. org/10.1590/1413-81232020251.27572019
2. Zug KE, Cassiani SHB, Pulcini J, Garcia AB, Aguirre-Boza F, Park J. Advanced practice nursing in Latin America and the Caribbean: regulation, education and practice. Rev Lat-Am Enfermagem. 2016;24(1):e2807. doi: https://doi. org/10.1590/1518-8345.1615.2807

3. Toso BRGO, Padilha MI, Breda KL. 0 eufemismo das boas práticas ou a prática avançada de enfermagem. Esc Anna Nery. 2019;23(3):e20180385. doi: https:// doi.org/10.1590/2177-9465-ean-2018-0385

4. Backes DS, Backes MTS, Erdmann AL, Büscher A. 0 papel profissional do enfermeiro no Sistema Único de Saúde: da saúde comunitária à estratégia de saúde da família. Ciênc Saúde Coletiva. 2012;17(1):223-30. doi: https://doi. org/10.1590/S1413-81232012000100024

5. Backes DS, Zamberlan C, Colomé J, Souza MT, Marchiori MT, Lorenzini AE, et al. Interatividade sistêmica entre os conceitos interdependentes de cuidado de enfermagem. Aquichan. 2016;16(1):24-31. doi: https://doi.org/10.5294/ aqui.2016.16.1.4

6. Avila LI, Silveira RS, Lunardi VL, Fernandes GF, Mancia JR, Silveira JT. Implications of the visibility of professional nursing practices. Rev Gaúcha Enferm. 2013;34(3):102-9. doi: https://doi.org/10.1590/ S1983-14472013000300013

7. Kieft RA, de Brouwer BB, Francke AL, Delnoij DMJ. How nurses and their work environment affect patient experiences of the quality of care: a qualitative study. BMC Health Serv Res. 2014;14:249. doi: https://doi. org/10.1186/1472-6963-14-249

8. Pan American Health Organization (US). Expanding the roles of nurses in primary health care. Washington, D.C.: PAH0; 2018.

9. Rafferty AM, Busse R, Zander-Jentsch B, Sermeus W, Bruyneel L, editors. Strengthening health systems through nursing evidence from 14 European countries. Copenhagen: WHO Regional Office for Europe; 2019 [cited 2020 Feb 03]. Available from: https://apps.who.int/iris/bitstream/hand le/10665/326183/9789289051743-eng.pdf?sequence=1\&isAllowed $=y$

10. Roma JC. Os objetivos de desenvolvimento do milênio e sua transiç̧ão para os objetivos de desenvolvimento sustentável. Cienc Cult. 2019;71(1):33-9. doi: https://doi.org/10.21800/2317-66602019000100011

11. Haron Y, Reicher S, Riba S. Factors influencing nursing career choices and choice of study program. Health Mark Q. 2014;31(2):167-77. doi: https://doi.org/10.1 080/07359683.2014.907126

12. Backes DS, Iha S, Weissheimer AS, Halberstadt BMK, Megier ER, Machado R. Socially entrepreneurial activities in nursing: contributions to health/ healthy living. Esc Anna Nery. 2016;20(1):77-82. doi: https://doi. org/10.5935/1414-8145.20160011

13. Corbin J, Strauss A. Basics of qualitative research: techniques and procedures for developing Grounded Theory. 4th ed. Los Angeles (CA): Sage; 2015.

14. Strauss A, Corbin J. Pesquisa qualitativa: técnicas e procedimentos para 0 desenvolvimento de teoria fundamentada. Porto Alegre: Artmed; 2008.

15. Lomba MLLF, Toson M, Weissheimer AS, Backes MTS, Büscher A, Backes DS. Empreendedorismo social: translação de saberes e práticas em estudantes de enfermagem no Brasil. Rev Enf Ref. 2018;serlV(19):107-15. doi: https://doi. org/10.12707/RIV18064

16. Machado MH, Frota MA, Wermelinger MCMW, Ximenes NFRG, Freire NP. Health and Nursing Systems: thenational andinternational context. Ciênc SaúdeColetiva. 2020;25(1):5. doi: https://doi.org/10.1590/1413-81232020251.28562019

17. BrandãoMA,Barros ALBL,Caniçali PC,BispoGS, LopesROP.Teorias deenfermagem na ampliação conceitual de boas práticas de enfermagem. Rev Bras Enferm. 2019;72(2):577-81. doi: https://doi.org/10.1590/0034-7167-2018-0395 
18. Reed PG, Shearer NBC. Nursing knowledge and theory innovation. 2nd ed. New York: Springer; 2017.

19. Alligood MR, Miles JM. Nursing knowledge and health policy in process. NursSci Q. 2012;24(1):7-8. doi: https://doi.org/10.1177/0894318410389069

\section{- Funding /Acknowledgment:}

National Council for Scientific and Technological Development (Conselho Nacional de Desenvolvimento Científico e Tecnológico). CNPq Process: 302103/2017-1.

\section{- Authorship contribution}

Dirce Stein Backes: Conceptualization; Formal analysis; Funding acquisition; Project administration; Writingoriginal draft; Writing-review \& editing.

Nathalia Hoffmann Adames: Conceptualization; Formal analysis; Investigation; Writing-original draft; Writingreview \& editing.

Amanda Schneider Weissheimer: Conceptualization; Formal analysis; Investigation; Writing-original draft; Writing-review \& editing.

Andreas Büscher: Formal analysis; Methodology; Visualization; Validation.

Marli Terezinha Stein Backes: Conceptualization; Formal analysis; Methodology; Writing-original draft; Writingreview \& editing.

Alacoque Lorenzini Erdmann: Formal analysis; Methodology; Visualization; Validation.

\section{- Corresponding author:}

Dirce Stein Backes

Email: backesdirce@ufn.edu.br
20. Santos MFTL, Macêdo CRC, Albuquerque GA, Meneses OR. Effective communication strategies for managing disruptive behaviors and promoting patient safety. Rev Gaúcha Enferm. 2019;40(spe):e20180308. doi: https://doi. org/10.1590/1983-1447.2019.20180308

\section{Associate editor:}

Dagmar Elaine Kaiser

\section{Editor-in-chief:}

Approved: 10.05.2020 